\title{
A SURVEY OF RICE - FIELD WEEDS IN RATNAPURA AND KURUNEGALA DISTRICTS OF SRI LANKA
}

\author{
J. P. N. R. CHANDRASENA \\ Department of Botany, University of Colombo, P. O. Box 1490, Colombo 3, Sri Lanka.
}

(Date of receipt : 24 February 1989)

(Date of acceptance : 09 August 1989)

\begin{abstract}
A survey of rice-field weeds was carried out in the Districts of Ratnapura and Kurunegala' during the 'Yala' and 'Maha' seasons of 1986. Two hundred and thirty four fields of the Ratnapura District and 196 ficlds of the Kurunegala District were sampled at a time when the rice was at heading to flowering and farmers had carried out weeding or herbicide applications for weed control. One hundred and forty seven species of weeds belonging to 95 genera and 37 plant families were recorded from the two districts, indicating a very rich diversity in the weed-flora. Of these, 38 species occurred in less than $10 \%$ of the fields; 65 spccies in $10-20 \%$ of the ficlds and 44 species in $20 \%$ or more fields. By far the commonest and problematic weeds were monocotyledons of the families Poaceae (Gramineae) and Cyperaceae. Threc grass specics Echinochloa crus-galli (L.)Beauv., Echinocbloa counum (L.) Link. and Ischatmum rugosum Salisb. emerged as the most abundant species in both districts, both in terms of frequency of occurrence and levels of infestation. Fimbristylis miliacia (L.)Vahl, Cy'perus :pilisus Vahl and Cyperus iria L. of the Cyperaceae were also very common in both Districts. Dicotyledonous weeds, although common in occurrence, generally did not present major problems to farmers, except Ludwigia byssopifolia (G. Don)Exell in the Ratnapura District. No major differences in the weed-flora of the two Districts were seen, despite the fact that the climate in Kurunegala was much drier than in Ratnapura. Farmer interviews during the survey revealed that the farmer populations in the areas surveyed lacked adequate knowledge of weeds, problems caused by weeds and cffective means of wced control.
\end{abstract}

\section{Introduction}

Rice-fields are invacied by terrestrial, semi-aquatic or aquatic plants depending on the type of rice-culture and the cropping season. ${ }^{5}$ In rain-fed rice-fields, all three groups of plants occupy the same physical location at different times of the year. During the cultivation of lowland rice, fields are subjected to flooding, ploughing and turning up of the soil, followed by a period of rice monoculture. Between the periods of rice culture, the fields are rapidly invaded by weeds which are mainly terrestrial in nature. During rice culture, a large number of aquatic or semi-aquatic weeds grow in the fields along with the rice. A knowledge of the composition of the weedflora, community patterns and effects of edaphic, climatic and biotic factors on growth and reproduction of weeds, helps to gain an insight into their mechanisms of specialization and distribution, and is hence important for their management and control.

During 1984 and 1985/1986, the author completed surveys of ricefield weeds in the Colombo, Gampaha, Kalutara and Galle Districts, all of which are located in the low-country Wet Zone of Sri Lanka. Comprehensive up-dated check lists of the rice--field weed flora in these Districts have 
been prepared as a result of this work. In addition to the floristic composition, evaluations of the abundance of rice-field weeds were also done, and the weeds ranked according to their relative abundance. ${ }^{2,3}$ One new species record for the island, viz. Ludwigia decurrens Walt., presently a major ricefield weed in the low country wet zone, was made in this work. ${ }^{4}$

The present project concentrated on two other Districts, namely Ratnapura and Kurunegala. The Ratnapura District is situated in the midsouthern quarter of the island and the Kurunegala District in the NorthWest (Figure 1). Both Districts are large in extent. Each has a fairly large part of its land located in the intermediate climatic zone, while parts of both are situated in the Dry Zone, as well as in the Wet Zone (Figure 1).

Rice cultivation is extensively done in the Kurunegala District, which is characterized by flat, undulating landscape, frequent droughts, and generally high air temperatures $\left(30-37^{\circ} \mathrm{C}\right)$. Rice culture in the Kurunegala District is mostly rainfed, but a very significant proportion of its fields receive water from major and minor irrigation schemes (Table 1) and the numerous small 'village tanks' spread throughout much of the District. Many of these are connected to form fairly extensive localized networks of irrigation. Rain received from both the North-East monsoon (NovemberFebruary) and South-West monsoon (April-August) is used for rice-culture over two seasons. In this district, cultivation is heavier during the North-East monsoon time, in the 'Maha' season. In general, Kurunegala District is widely regarded as one of the most productive rice-growing districts (Table 1), in addition to being important for its extensive coconut plantations.

Ratnapura District still has a fairly extensive wet zone forest cover within its boundaries. Plantation agriculture, mainly rubber and tea, also take up a fair extent of its land. The land rises up to mid-elevations of about 500-700 m above mean sea level in several parts of the District. Rice culture is mainly done on the flatter terrain, generally close to the multitude of towns and along the sides of the major transport routes. Rice-cultivation in the District is mainly dependent on rainfall received from both monsoons. Heavier cultivation is during the South-West monsoon in the 'Yala' season. However, water from minor and major irrigation schemes is also used for rice culture (Table 1).

The overall objective of the survey, as described previously,,$^{2,3}$ was to improve the status of knowledge regarding the floristic composition of the rice-field weed flora of the two Districts, and to make an evaluation of the relative abundance of each species, in order to rank them according to importance. 


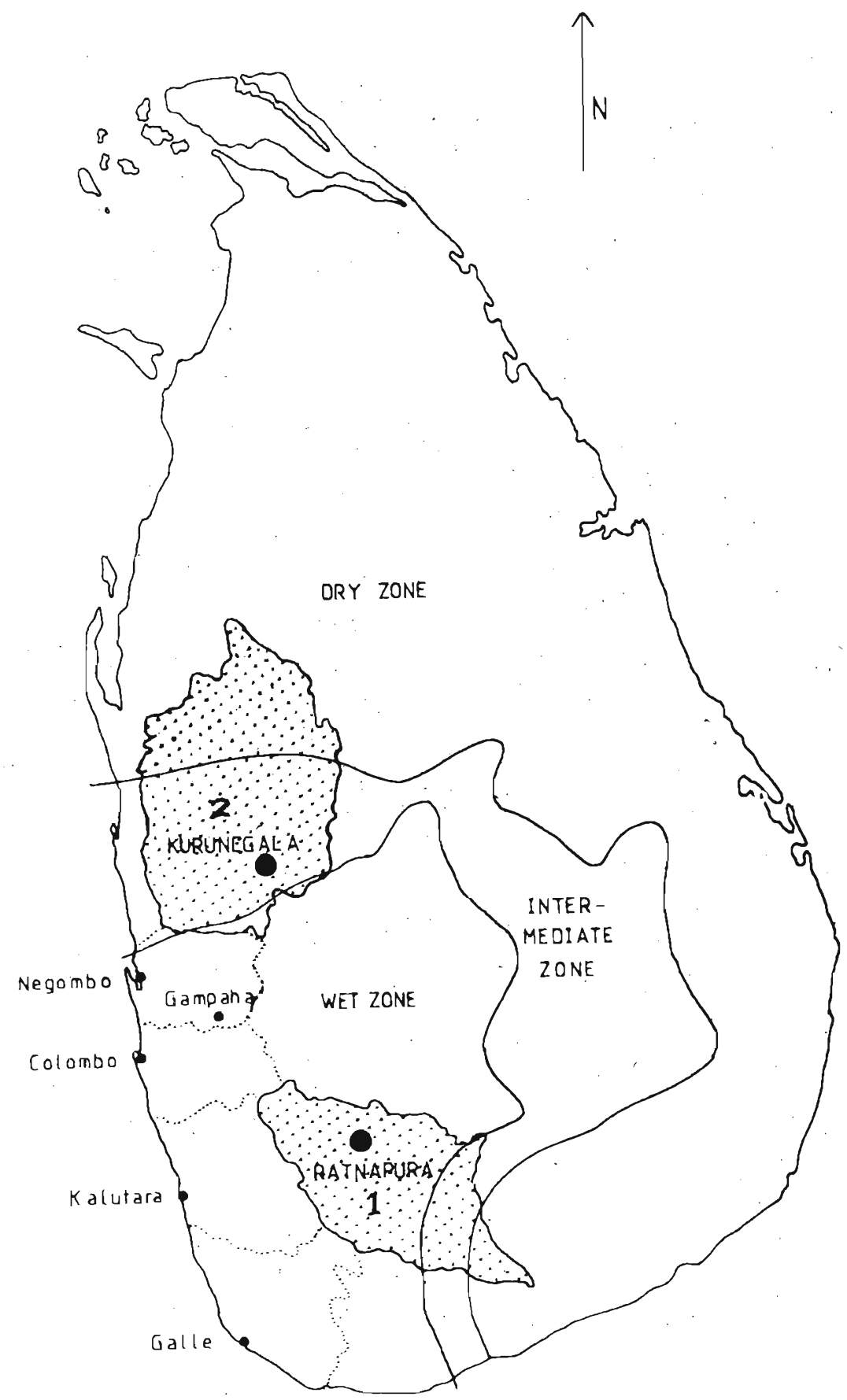

Figure 1. A Map of Sri Lanka indicating the Dry, Intermediate and Wet Zones of the island and the two Districts surveyed, (1) Ratnapura and (2) Kurunegala Districts. Gampaha, Colombo, Kalutara and Galle Districts which were surveyed earlier are also indicated. 


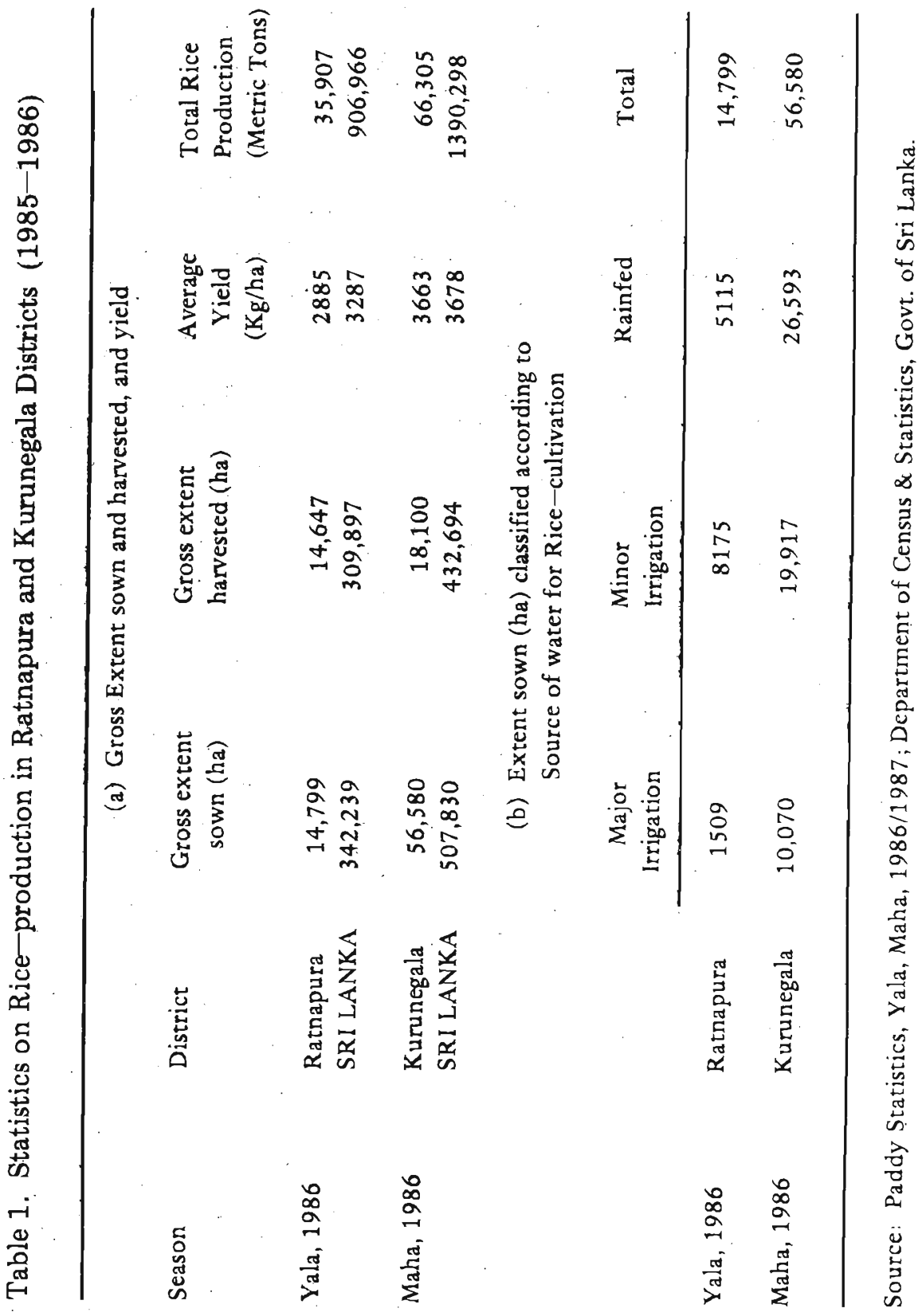




\section{Materials and Methods}

Rice-field weed surveys were carried out mainiy in the Yala, 1986 (Ratnapura District) and Maha, 1986/1987 (Kurunegala District) seasons.

The two Districts and their major road networks are given in Figures 2 and 3. Only fields adjacent to the motorable roads were assessed in this survey, mainly because of the very large extents of the two Districts. Villages for sampling of their rice-fields were selected at random by driving along. the roads marked on the maps. In areas where large acreages were under rice, fields were assessed at approximately $1 \mathrm{~km}$ intervals and wherever possible on alternate sides of the road. Where the rice growing areas were few and scattered, fields were assessed irrespective of the distance between two sites. However, in all cases efforts were made to ensure that at least a gap of $1 \mathrm{~km}$ separated two successive sampling sites. In each village where sampling was done, two rice-fields were assessed. In the present work, 98 villages (196 fields) from the Kurunegala District and 117 villages (234 fields) from the Ratnapura District were surveyed.

At the time of survey, the rice was most commonly found to be at the heading to flowering stage. It was found that in the great majority of the sampled fields, farmers had already carried out some degree of weed control. Thus, the species recorded here were those that had survived the farmers' control measures, or those which had been overlooked. Some weeds recorded in the survey, however, could have grown out of seeds that germinated after the farmers had carried out their control measures.

Each field was surveyed by walking along bunds and recording all weed species which were present. Several 'liyaddes' ('liyadde' is an area surrounded by an earthen bund) in each field were examined. Weeds growing in the rice-field which were visible above or among the rice canopy, were scored for infestation level by scanning the whole field. Those occurring below the canopy of rice were scored by carefully examining a minimum of four approximately $1 \mathrm{~m}$ areas selected at random within each field. Scores were then averaged over the four plots. The following rating scale, based mainly on percentage cover with respect to the whole field, was used for infestation levels: $0=$ species not present $; 1=$ a few scattered plants: $2=$ $1-25 \%$ weed cover, moderately infested; $3=26-50 \%$ weed cover, serious infectation ; $4=51-75 \%$ weed cover, very serious infestation; $5=76-100 \%$ weed cover, weed species completely dominant and masking the crop. The frequency of occurrence with respect to the total number of sample fields studied per District was computed for each species, along with relative abundance in each rating category.

Wherever possible, the farmers who had cultivated the fields sampled were interviewed and questioned regarding the weed species that were usually present, control practices used, and their general know-how about weeds and weed management. 


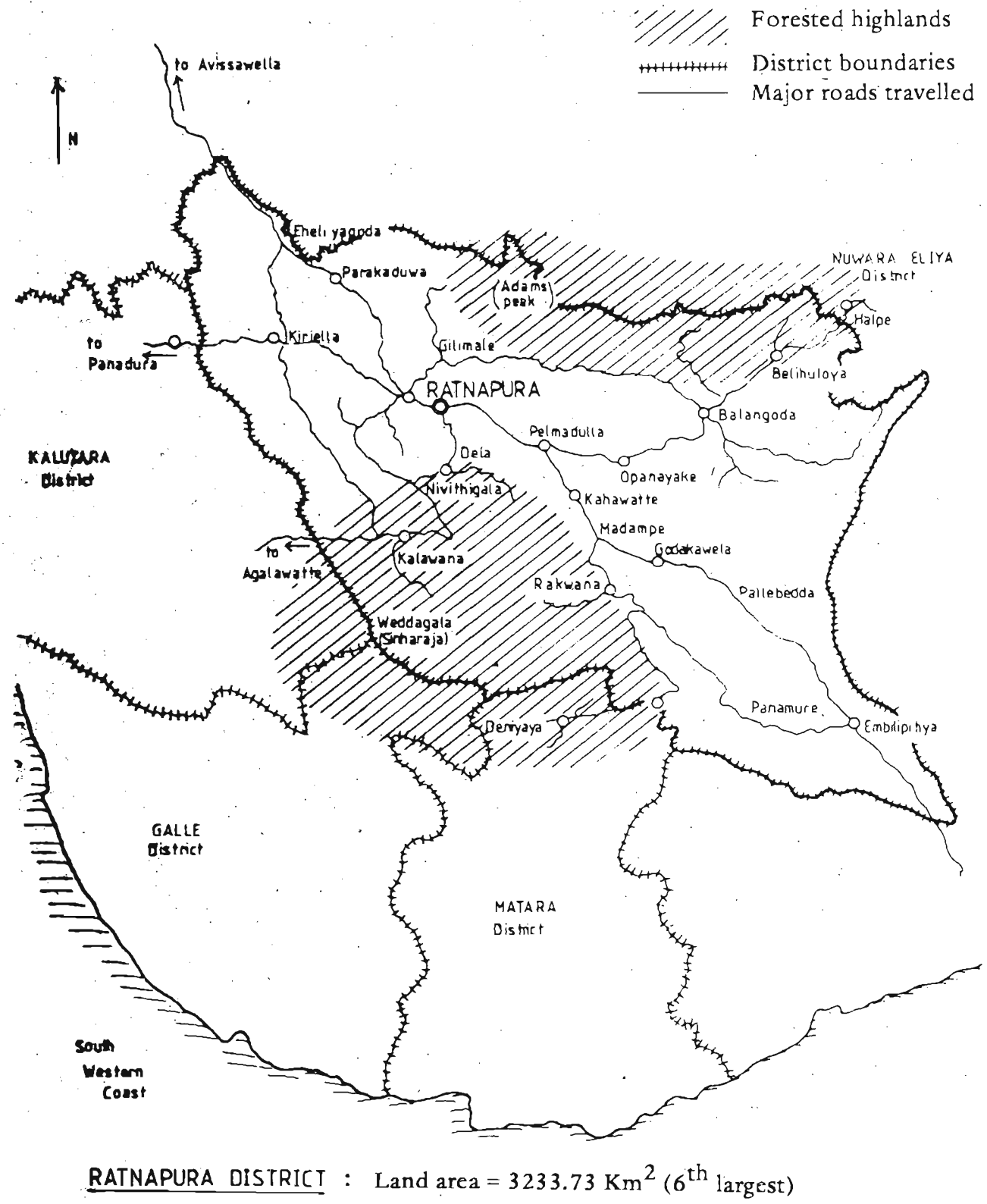

Figure 2. A Map of Ratnapura District showing major towns and roads travelled during the survey. 


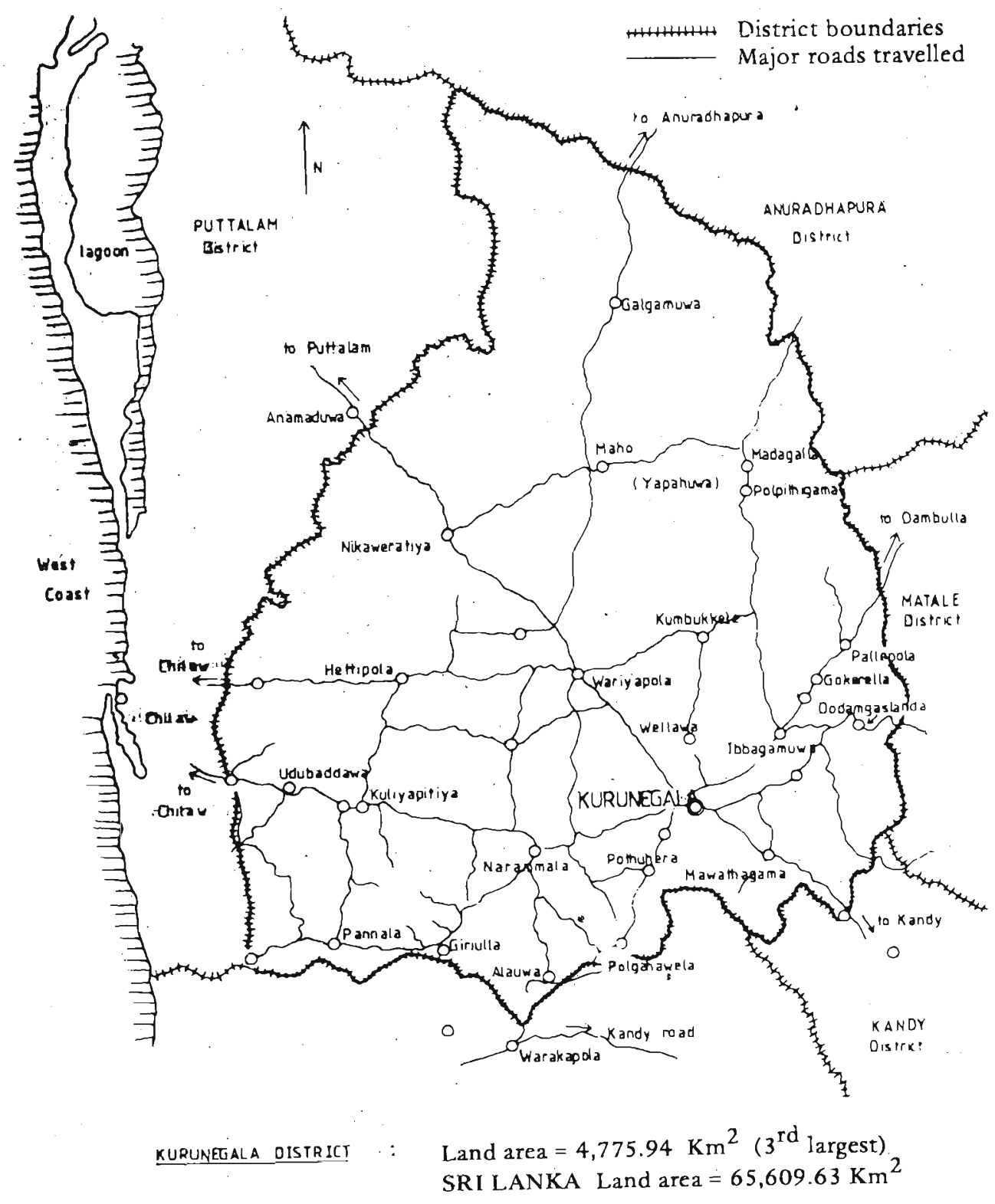

Figure 3. A Map of Kuru negala District showing major towns and roads travelled during the survey. 


\section{Results and Discussion}

Table 2 provides a complete list of all weed species encountered in the field and bund habitats of the rice-fields sampled from the two Districts. A total of 147 weed species, assigned to 95 genera and 37 families, were recorded in the present survey. Of these, 38 species occurred in less than $10 \%$ of fields sampled: 65 species occurred in 10-20\% fields; and 44 species occurred in $20 \%$ or more fields. The families to which the commonest rice-field weeds belonged were: Cyperaceae (33 spp.) and Poaceae (24 spp.). Other families such as Asteraceae (11 spp.), Scrophulariaceae (9 spp.), Fabaceae (9 spp.), Onagraceae ( $5 \mathrm{spp}$.) and Rubiaceae (5 spp.) were also well represented within the rice--agroecosystem in the samples studied.

Table 2. Floristic Composition of rice-field weeds in Ratnapura and Kurunegala Districts, indicating their occurrence and major habitat in the rice-agroecosystem (Yala, Maha seasons, 1986).

Species \& Family.

\section{Occurrence}

Mollugo oppositifolia L.

3. AMARANTHACEAE

Alternanthera sessilis (L.) DC.

Amarantbus spinosus L.

Gompbrena celosioides Mart.

4. APIACEAE

Centella asiatica (L.) Urb.

5. ARACEAE

Pistia stratiotes $\mathrm{L}$.

Typbonium trilobatum (L.) Schult.

6. ASTERACEAE

Acanthospermum bispidum DC.

Ageratum conyzoides L.

Eclipta prostrata (L.) L.

Emilia sonchifolia (L.) DC. ex Wight

Epaltes divaricata (L.) Cass.

Spbaerantbus africanus $\mathrm{L}$.

Sphaerantbus indicus L.

Spilantbes paniculata Wall. ex DC. occasional

occasional

$\begin{array}{ll}\text { frequent } & \text { B,F } \\ \text { occasional } & \text { B } \\ \text { frequent } & \text { B }\end{array}$

frequent

B

occasional

F,D

frequent

B

Major

Habitat

B

B

B,F

B

B

occasional B

frequent $B$

widespread $\quad \mathrm{B}, \mathrm{F}$

occasional B

occasional B

frequent $\quad B, F$

frequent $\mathbf{B}, \mathbf{F}$

occasional B 
(Table 2. contd.)

\begin{tabular}{clc}
\hline Species \& Family & Occurrence & $\begin{array}{c}\text { Major } \\
\text { Habitat }\end{array}$ \\
\hline Synedrella nodiflora (L.) Gaertn. & frequent & B \\
Tridax procumbens L. & frequent & B \\
Vernonia cinerea (L.) Less. & widespread & B \\
7. BORAGINACEAE & & \\
Heliotropium indicum L. & frequent & B
\end{tabular}

8. BUTOMACEAE

Limnocharis flava (L.) Buchen.

widespread F,B,D

9. CAPPARIDACEAE

Cleome burmani Wight \& Arn.

Cleome viscosa $\mathrm{L}$.

frequent B

frequent $B$

10. COMMELINACEAE

Commelina benghalensis $\mathrm{L}$.

Commelina diffusa Burm. $\mathrm{f}$.

frequent

B

widespread

B, F, D

11. CONVOLVULACEAE

Ipomoea aquatica Forsk.

Ipomoea triloba $\mathrm{L}$.

frequent

B, D

frequent

$\mathrm{B}, \mathrm{F}$

12. CYPERACEAE

Cyperus compressus L.

Cyperus difformis L.

Cyperus distans L.F.

Cyperus baspan $\mathrm{L}$.

Cyperus iria $\mathrm{L}$.

Cyperus pilosus Vahl

Cyperus procenus Rottb.

Cyperus rotundus $\mathrm{L}$.

Cyperus sphacelatus Rottb.

Eleocharis acutangula (Roxb.) Schult.

Eleocharis dulcis (Burm.f.) Trin. ex Henschel

Fimbristylis acuminata Vahl

Fimbristylis dichotoma (L.) Vahl

Fimbristylis ferruginea (L.) Vahl

Fimbristylis umbellaris (l,am.) Vahl

Fimbristylis miliacea (L.) Vahl

Fimbristylis schoenoides (Retz.) Vahl

Fimbristylis tetragona $\mathrm{R}$. $\mathrm{Br}$.

Fuirena ciliaris (L.) Roxb.

$\begin{array}{ll}\text { frequent } & \mathrm{B} \\ \text { occasional } & \mathrm{F}, \mathrm{B} \\ \text { occasional } & \mathrm{F}, \mathrm{D} \\ \text { widespread } & \mathrm{F}, \mathrm{B}, \mathrm{D} \\ \text { widespread } & \mathrm{F}, \mathrm{B}, \mathrm{D} \\ \text { widespread } & \mathrm{F}, \mathrm{B}, \mathrm{D} \\ \text { frequent } & \mathrm{B} \\ \text { widespread } & \mathrm{B} \\ \text { frequent } & \mathrm{B} \\ \text { frequent } & \mathrm{F} \\ \text { widespread } & \mathrm{B} \\ \text { widespread } & \mathrm{B}, \mathrm{F} \\ \text { widespread } & \mathrm{B}, \mathrm{F} \\ \text { widespread } & \mathrm{B} \\ \text { occasional } & \mathrm{B}, \mathrm{F} \\ \text { widespread } & \mathrm{F}, \mathrm{B}, \mathrm{D} \\ \text { widespread } & \mathrm{B}, \mathrm{F} \\ \text { widespread } & \mathrm{B}, \mathrm{F}, \mathrm{D} \\ \text { occasional } & \mathrm{B}, \mathrm{F} \\ \text { frequent } & \mathrm{F}, \mathrm{B}\end{array}$

Fuirena umbellata Rottb. 
(Table 2. contd.)

\begin{tabular}{|c|c|c|c|c|}
\hline & Species \& Family & Occurrence & \multicolumn{2}{|l|}{$\begin{array}{l}\text { Major } \\
\text { Habitat }\end{array}$} \\
\hline & Fuirena capitata (Burm.f.) T.Koyama & frequent & \multicolumn{2}{|l|}{$\mathrm{B}, \mathrm{F}$} \\
\hline & Kyllinga brevifolia Rottb. & widespread & \multirow{2}{*}{\multicolumn{2}{|c|}{$\mathrm{B}, \mathrm{F}, \mathrm{D}$}} \\
\hline & Kyllinga nemoralis (J.R. \& G. Forst.) & & & \\
\hline & Dandy ex Hutchinson \& Dalziel & frequent & \multicolumn{2}{|l|}{ B } \\
\hline & Kyllinga bulbosa Beauv. & widespread & \multicolumn{2}{|l|}{$\mathrm{B}$} \\
\hline & Mariscus compactus (Retz.) Boldingh & occasional & \multicolumn{2}{|l|}{$B, D$} \\
\hline & Mariscus paniceus (Rottb.) Vahl & occasional & \multicolumn{2}{|l|}{ B } \\
\hline & Pycreus polystachyos (Rottb) Beauv. & frequent & \multicolumn{2}{|l|}{ B } \\
\hline & Pycreus pumilus (L.) Nees & occasional & \multicolumn{2}{|l|}{$\mathrm{B}$} \\
\hline & Rbynchospora corymbosa (L.)Britton & occasional & \multicolumn{2}{|l|}{$\mathrm{B}, \mathrm{D}, \mathrm{F}$} \\
\hline & Scboenoplectus articulatus (L.)Palla & occasional & \multicolumn{2}{|l|}{$\mathrm{F}$} \\
\hline & Scboenoplectus juncoides (Roxb.)Palla & widespread & \multicolumn{2}{|l|}{$F, B, D$} \\
\hline & Schoenoplectus grossus (L.f.)Palla & frequent & \multicolumn{2}{|l|}{$\mathrm{F}, \mathrm{B}, \mathrm{D}$} \\
\hline & Scleria poaeformis Retz. & occasional & \multicolumn{2}{|l|}{$\mathrm{B}, \mathrm{F}$} \\
\hline \multirow[t]{3}{*}{13.} & ERIOCAULACEAF & & \multicolumn{2}{|l|}{. } \\
\hline & Eriocaulon quinquangulare $\mathrm{L}$. & widespread & \multicolumn{2}{|l|}{$\mathrm{F}$} \\
\hline & Eriocaulon sexangulare $\mathrm{L}$. & widespread & \multicolumn{2}{|l|}{$\mathrm{F}$} \\
\hline \multirow[t]{5}{*}{14.} & EUPHORBIACEAE & & \multirow{2}{*}{\multicolumn{2}{|c|}{ B }} \\
\hline & Croton birtus L'Herit & frequent & & \\
\hline & Eupborbia birta L. & frequent & \multicolumn{2}{|l|}{ B } \\
\hline & Pbyllantbus debilis Klein ex Willd. & frequent & \multicolumn{2}{|l|}{$\mathrm{F}, \mathrm{B}$} \\
\hline & Pbyllanthus urinaria L. & frequent & \multicolumn{2}{|l|}{ B } \\
\hline \multirow[t]{10}{*}{15.} & FABACEAE (LEGUMINOSAE) & & & \\
\hline & Aescbynomene aspera $\mathrm{L}$. & frequent & \multicolumn{2}{|l|}{$\mathrm{F}, \mathrm{B}$} \\
\hline & Aescbnomene indica $\mathrm{L}$. & frequent & \multicolumn{2}{|l|}{$\mathrm{F}, \mathrm{B}$} \\
\hline & Alyssicarpus vaginalis DC. & frequent & \multicolumn{2}{|l|}{ B } \\
\hline & - Cassia tora L. & occasional & B & \\
\hline & Desmodium heterocarpum (L.) DC. & frequent & $\mathrm{B}, \mathrm{D}$ & \\
\hline & Desmodium beterophyllum (Willd.) DC. & frequent & $\mathrm{B}, \mathrm{D}$ & \\
\hline & Desmodium triflorum (L.) DC. & frequent & $B, D$ & \\
\hline & Mimosa pudica $\mathrm{L}$ & widespread & B & \\
\hline & Tepbrosia purpurea (L.) Pers. & occasional & B & \\
\hline 16. & GENTIANACEAE & & & \\
\hline & Nymphoides indica (L.) O.K. & frequent & B & \\
\hline 17. & HYDROCHARITACEAE & & & \\
\hline & Blyxa octandra (Roxb.) Planch. ex Thw. & occasional & $\mathrm{D}, \mathrm{F}$ & . \\
\hline & Hydrilla verticillata (L.f.) Royle & frequent & $\mathrm{D}$ & \\
\hline & Ottelia alismoides (L.) Pers. & occasional & $\underline{\mathrm{D}}, \mathrm{F}$ & \\
\hline
\end{tabular}


(Table 2. contd.)

Species \& Family
Occurrence

occasional

occasional

frequent

widespread

frequent.

F

Utricularia reticulata Sm.

21. LYTHRACEAE

Ammania baccifera $\mathrm{L}$.

Ratala densiflora (Roth ex Roem. \&

Schult.) Koehne

20. LENTIBULARIACEAE

Hyptis capitata Jacq.

Hyptis suaveolens (L.) Poit.

Leucas zeylanica (L.) R. Br.

occasional

frequent

F
Major

Habitat

$\mathrm{B}, \mathrm{F}$

22. MALVACEAE

Sida rbombifolia L.

frequent

B

Urena lobata L.

frequent

B

23. MARSILIACEAE

Marsilea quadrifolia L.

frequent

F,D

24. NYCTAGINACEAE

Boerbavia erecta $\mathrm{L}$.

occasional

B

25. ONAGRACEAE

Ludwigia adscendens (L.) Hara

Ludwigia decurrens Walt.

Ludwigia byssopifolia (G. Don) Exell

Ludwigia octovalvis (Jacq.) Raven

Ludwigia perennis $\mathrm{L}$.

$\begin{array}{ll}\text { occasional } & \text { F,D } \\ \text { widespread } & \text { F,B } \\ \text { widespread } & \text { F,B } \\ \text { occasional } & \text { B } \\ \text { frequent } & \text { F,B }\end{array}$

26. POACEAE (GRAMINEAE)

Alloteropsis cimicina (L.) Stapf

Axonopus affinis Chase

Axconopus compressus (Sw.) Beauv.

Echinocbloa colonum (L.) Link.

Ecbinocbloa crus-galli (L.) Beauv.

Eleusine indica (L.) Gaertn.

frequent

widespread

B

frequent

B, D

widespread

$B, D$

widespread

$F, B, D$

$\mathrm{F}, \mathrm{B}$

widespread

B,D

frequent

$B, D$

Eragrostis gangetica (Roxb.) Steud.

Eragrostis tenella (L.) Beauv. ex Roem \& Schult

occasional

B 
(Table 2. contd.)

Species \& Family

Occurrence

Major

Habitat

Eragrostis unioloides (Retz.) Nees ex Steud.

Isacbne globosa (Thurib.) Kuntze

Ischaemum indicum (Houtt.) Merr.

Ischaemum rugosum Salisb.

Leersia bexandra Sw.

Leptocbloa chinensis (L.) Nees

Oryza rufipogon Griff.

Panicum maximum Jacq.

Panicum repens (L.) Beauv.

Paspalum commersonii Lam.

Paspalum conjugatum Berg.

Pennisetum polystachyon (L.) Schult.

Sacciolepis indica (L.) Chase

Sacciolepis interrupta (Willd.) Stapf

Setaria geniculata (Lam.).Beauv.

Sporobolsus diandrus (Retz.) Beauv.

27. POLYGONACEAE

Polygonum barbatum L.

Polygonum glabrum Willd.

frequent

B,D

occasional

B, D

28. PONTEDERIACEAE

Eichbornia crassipes (Mart.) Solms

Monochoria vaginalis (Burm.f.) Kunth

frequent

D

widespread

F, D, B

29. RUBIACEAE

Borreria alata (Aubl.) DC.

Hedyotis corymbosa (L.) Lamk.

Knoxia zeylanica L.

Mitracarpus hirtus (L.) DC.

Spermacoce bispida L.

widespread

B

frequent

$\mathrm{B}, \mathrm{F}$

widespread

$F, B, D$

$\mathrm{B}$

$\mathrm{F}, \mathrm{B}$

$B, D, F$

$B, D$

$\mathrm{F}$

B

$B, F, D$

$B, F$

$\mathrm{B}$

$\mathrm{B}$

$\mathrm{B}, \mathrm{F}$

$\mathrm{F}, \mathrm{B}$

$\mathrm{B}, \mathrm{F}$

$\mathrm{B}$

frequent . $B$

frequent $B$

30. SALVINIACEAE

Azolla pinnata Lam.

Salvinia molesta D.S. Mitchell

occasional

F,D

widespread

F,D

31. SCROPHULARIACEAE

Bacopa monnieri (L.) Pennell

Limnopbila aquatica (Roxb.) Alston

Limnophila aromatica (Lam.) Merr.

Limnopbila repens (Benth.) Benth.

Lindernia anagallis (Burm.f.) Pennell

$\begin{array}{ll}\text { frequent } & \text { F,B } \\ \text { frequent } & \text { F,D } \\ \text { occasional } & \text { F,D } \\ \text { widespread } & \text { F,B,D } \\ \text { frequent } & \text { F,B }\end{array}$


(Table 2. contd.)

\begin{tabular}{lll}
\hline Species \& Family & Occurrence & $\begin{array}{c}\text { Major } \\
\text { Habitat }\end{array}$ \\
\hline Lindernia antipoda (L.) Alston & frequent & F,B \\
Lindernia byssopioides (L.) Haines & widespread & F,B,D \\
Lindernia rotundifolia (L.) Alston & widespread & F,B,D \\
Scoparia dulcis L. & widespread & B
\end{tabular}

32. SOLANACEAE

Pbysalis angulata L.

occasional

B

33. SPHENOCLEACEAE

Sphenoclea zeylanica Gaertn.

occasional

B

34. STERCULIACEAE

Melocbia corcborifolia L.

widespread

$\mathrm{B}, \mathrm{F}$

35. TILIACEAE

Triumfetta rbomboidea Jacq.

occasional

B

36. VERBENACEAE

Pbyla nodiflora (L.) Green

Stachytarpbeta indica (L.) Vahl

Stachytarpheta jamaicensis (L.) Vahl

$\begin{array}{ll}\text { occasional } & B \\ \text { frequent } & B \\ \text { frequent } & B\end{array}$

37. XYRIDACEAE
Xyris indica $\mathbf{L}$.
frequent
F,D
a widespread $=$ most common and widely distributed; frequent $=$ less common, yet frequently found also with wide distribution; occasional = least common, patchy in appearance
${ }^{\mathrm{b}} \mathrm{B}=$ Bund; $\mathrm{D}=$ Ditch (irrigation channel); $\mathrm{F}=$ Field

\subsection{Ratnapura district}

\subsubsection{Monócotyledonous weeds}

Table 3 gives the occurrence of the commonest monocotyledonous weeds present in the District. Thirteen species were obserred with a frequency of $50 \%$ or more in the fields surveyed. Echinochloa crus galli and Echinochloa colonum were the most frequently recorded weeds. Both were present in $90 \%$ or more of the fields surveyed. However, at the time of sampling only $18 \%$ of fields had $E$. crus galli at serious infestation levels of 3 and above. This figure was $10 \%$ for E.colonum. Therefore it was clear that in the majority of the fields sampled these two top ranking species showed low to moderate levels of infestation. 


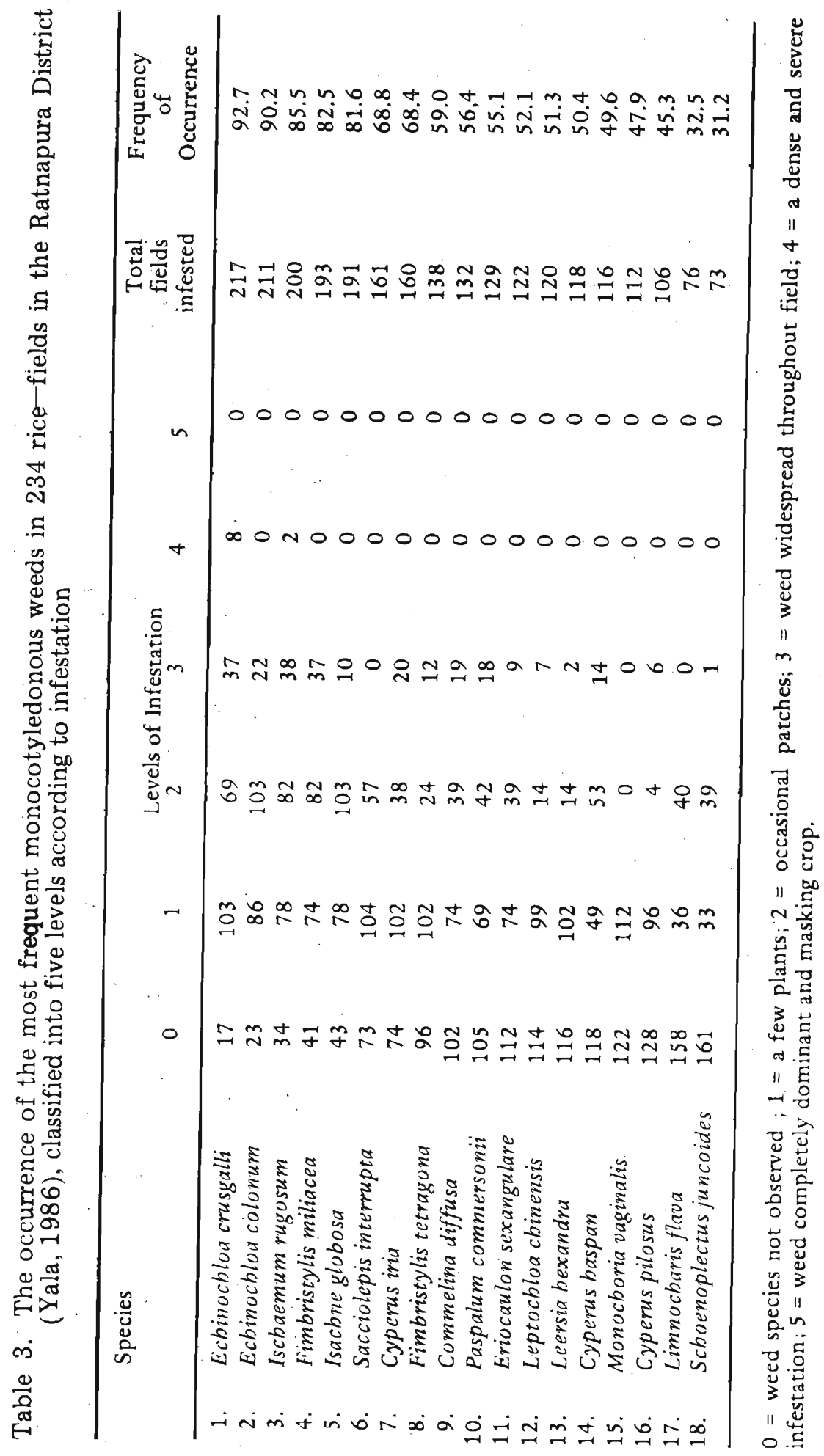


Ischaemum rugosum appeared as the third top-ranking species of the Ratnapura District rice-weec flora, with a frequency of occurrence of $85 \%$ from the fields surveyed. Of these infestations $20 \%$ received a score of 3 or more indicating its seriousness as a major weed. The farmer interviews clearly revealed that this weed had rapidly become the one that caused the greatest concern to the farmers in the District.

Fimbristylis miliacea and Isachne globosa, two weeds which were ranked as the top two in Colombo, Gampaha, Kalutara and Galle Districts of the low-country Wet Zone, ${ }^{3}$ were also present at high frequency in the Ratnapura District, the frequencies of occurrence being $82 \%$ and $81 \%$ respectively of the fields surveyed. Their infestations were however low to moderate and it was also apparent that towards the latter part of the growing season of rice, both these weeds were less dominant. Fimbristylis miliacea is known to complete its life cycle in the first three months of the season, and I. globosa generally spreads and dominates the rice agro-ecosystem, mainly during the fallow period between two seasons.

Sacciolepis interrupta a weed which ranked 5th in Kalutara and Galle Districts, but was not a major weed in Gampaha and Colombo Districts, ${ }^{2,3}$ was ranked 6th in Ratnapura with a frequency of occurrence of $69 \%$. However, its infestation level was not very high and none of the fields examined received a score of 3 or above.

Cyperus iria, a very common sedge-weed which ranked 3rd in Colombo and Gampaha Districts, and 7 th in Kalutara and Galle, was recorded from $68 \%$ of fields in Ratnapura. Of these infestations, $12 \%$ received a score of 3 and above indicating that $C$. iria was a serious weed in many situations.

Several other common monocotyledonous weeds also had frequencies of occurrence greater than $50 \%$ in the District. This list included Fimbristylis tetragona, Commelina diffusa, Paspalum commersonii, Eriocaulon sexangulare, Leptochloa chinensis and Leersia hexandra. However, as shown in Table 3 , in the majority of these situations, these weeds were present only in small numbers or as occasional patches in the fields sampled. Widespread infestations were recorded only for $F$. tetragona, $C$. diffusa and $P$. commersonii which received scores above 3 for $8-14 \%$ of the fields sampled. 


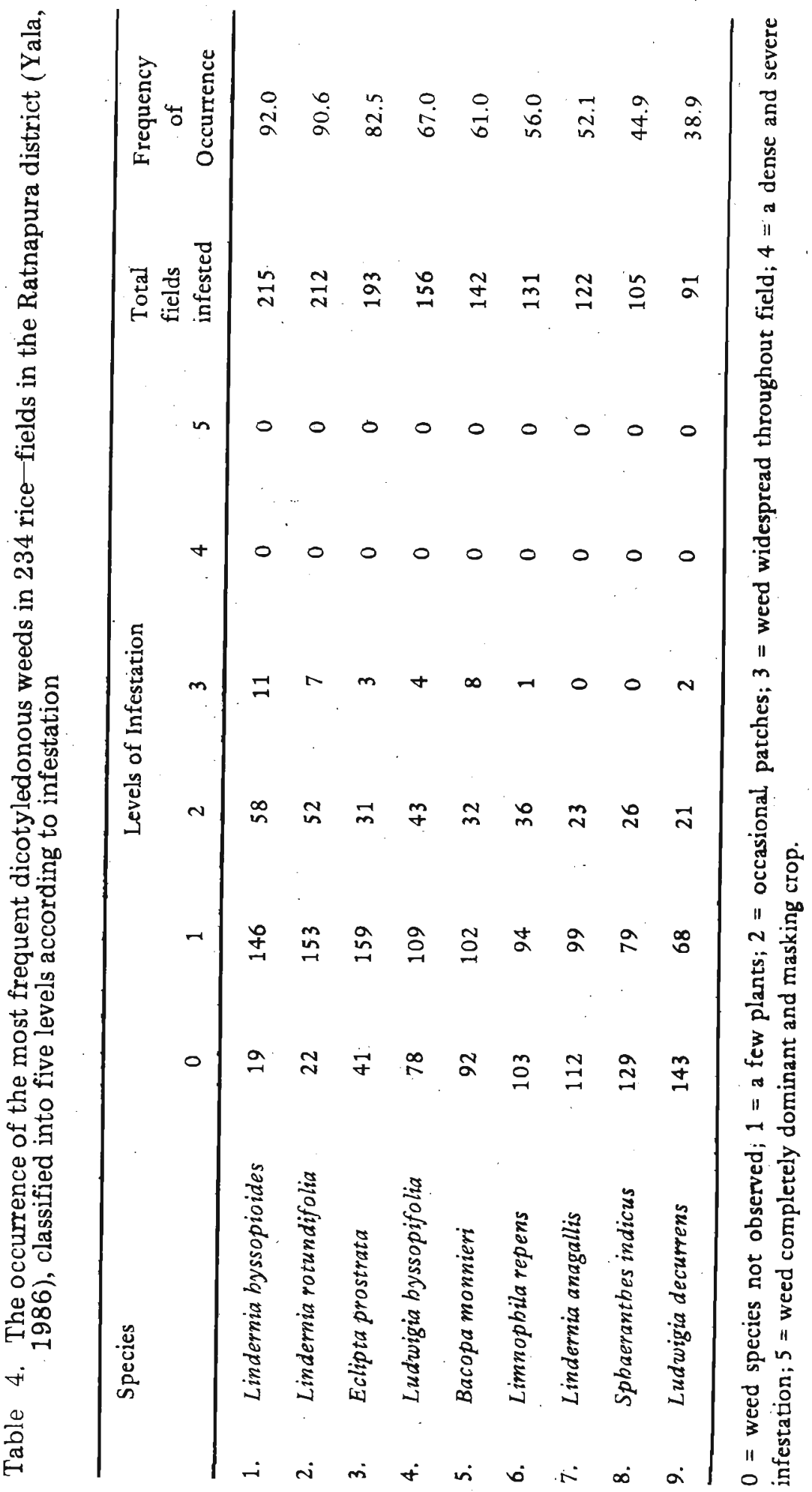


Cyperus haspan, a sedge-weed which was ranked 8th in Colnmhe wad Gampaha, and 10th in Kalutara and Galle, occurred in $49.6 \%$ fields sampled in Ratnapura and $12 \%$ of these infestations were heavy. Cyperus pilosus, another very prominent sedge-weed ranked 4th in Colombo, Gampaha, Kalutara and Galle Districts, was found only in $45 \%$ of fields in Ratnapura and in these too at low to moderate infestation levels.

Monochoria vaginalis, Limnocharis flava and Schoenoplectus juncoides with frequencies of occurrence of $48 \%, 32.5 \%$ and $31 \%$ respectively, were the other noteworthy monocotyledonous weeds in the rice-fields of the District. In general, the most important monocotyledonous weeds of the Ratnapura District were the same as in Colombo, Gampaha, Kalutara and Galle Districts.

\subsubsection{Diculyledonous weeds}

Of the dicotyledonous species recorded, the most important ones and their levels of abundance are given in Table 4. Two species of Lindernia, namely Lindernia hyssopioides and Lindernia rotundifolia and Eclipta prostrata took the top three positions, with frequencies of occurrence ranging from 8292\%. Their infestations were however not heavy, and hence these three species probably do not pose major problems to the farmer.

Ludwigia hyssopifolia, ranked 1st in all four Districts previously studied, ${ }^{2,3}$ occurred in $67 \%$ of fields and was the fourth most prevalent dicotyledonous weed in Ratnapura. Surprisingly, unlike in other Districts, heavy infestations were few ( 4 out of 156 fields.) in the fields examined. Its close ally, Ludwigia decurrens, occurred in $39 \%$ of fields, establishing the fact that this relatively recently introduced weed $^{1}$ has now expanded its distribution. A third species of Ludwigia, Ludwigia perennis, was found only at Embilipitiya in several fields. Embilipitiya is located in the SouthEast corner of the Ratnapura District, in the dry zone, and these habitats were noted to be generally drier than the rest of the District.

Other common dicotyledonous weeds recorded from the field habitat were generally similar to those found in the Districts studied previously. Bacopa monnieri,Limnophila repens, Lindernia anagallis and Sphaeranthes indicus were recorded from $45-61 \%$ of fields sampled. However, these species too were found mainly at low levels of infestation and as such do not present major problems in the rice-culture of the District.

\subsection{Kurunegala District}

A very large number of rice-fields in the District was found to be receiving inadequate moisture during both the Yala (1986) and the more important Maha season (1986). Drought conditions prevailed during much of the cultivation season in most parts of the District, except in its South-east corner (Mawathagama-Kandy road). 


\subsubsection{Monocotyledonous weeds}

Ischaemum rugosum, the aggressive grass-weed, was found to be the most dominant weed in the District (Table 5). It occurred in $93 \%$ of fields examined and $1 / 5$ th of its infestations were heavy receiving scores of 3 or more. The farmers interviewed expressed the view that in recent decades this weed had become one of the most troublesome weeds of the area. As revealed in the present survey, $I$. rugosum appeared to dominate rice-fields under a wide range of moisture conditions, varying from wet, through semidry to very dry. This weed has probably acquired greater significance during the last decade, since Weerakoon and Gunawardena in their survey of 1975 recorded this weed only in 25-50\% of fields surveyed and stated its relative abundance as fairly moderate in-both the dry and wet zone of the island. In the present surveys, $I$. rugosum occurred as the 3rd ranking weed in Ratnapura, Kalutara and Galle Districts, while in Gampaha and Colombo its position was 9 th. $^{2,3}$

The two species of the grass genus Echinochloa, namely E. crus galli and $E$. colonum, were also found at high levels of occurrence with low to moderate infestations. Echinochloa crus galli was recorded from $88 \%$ of the fields sampled and E. colonum from $83 \%$ of fields. In the majority of situations however, these weeds occurred as isolated plants or occasional patches, rather than as widespread infestations.

Cyperus pilosus, F. miliacea, C. iria and I. globosa, which were major weeds of the four Districts studied previously, 3 all occurred at frequencies of occurrence in the range of $51-53 \%$ in the fields of Kurunegala District. In general the infestations were noted to be low and not as heavy as recorded from the wetter Districts in 1984 and 1985.

As indicated in Table 5, all other monocotyledonous weeds occurred at less than $50 \%$ frequency in the rice-fields sampled. The majority of these were found to be at low to moderate infestation levels, unlike in the wetter Districts of Gampaha, Colombo, Kalutara, Galle and Ratnapura.

\subsubsection{Dicotyledonous weeds}

The dicotyledonous weed-flora of the rice-field habitat was also found to be not very variable and not heavy in infestation levels (Table 6). The two species of Lindernia, L. hyssopioides and L. rotundifolia, occurred in 81$84 \%$ of fields sampled, but generally only as scattered patches which never reached problematic proportions. 


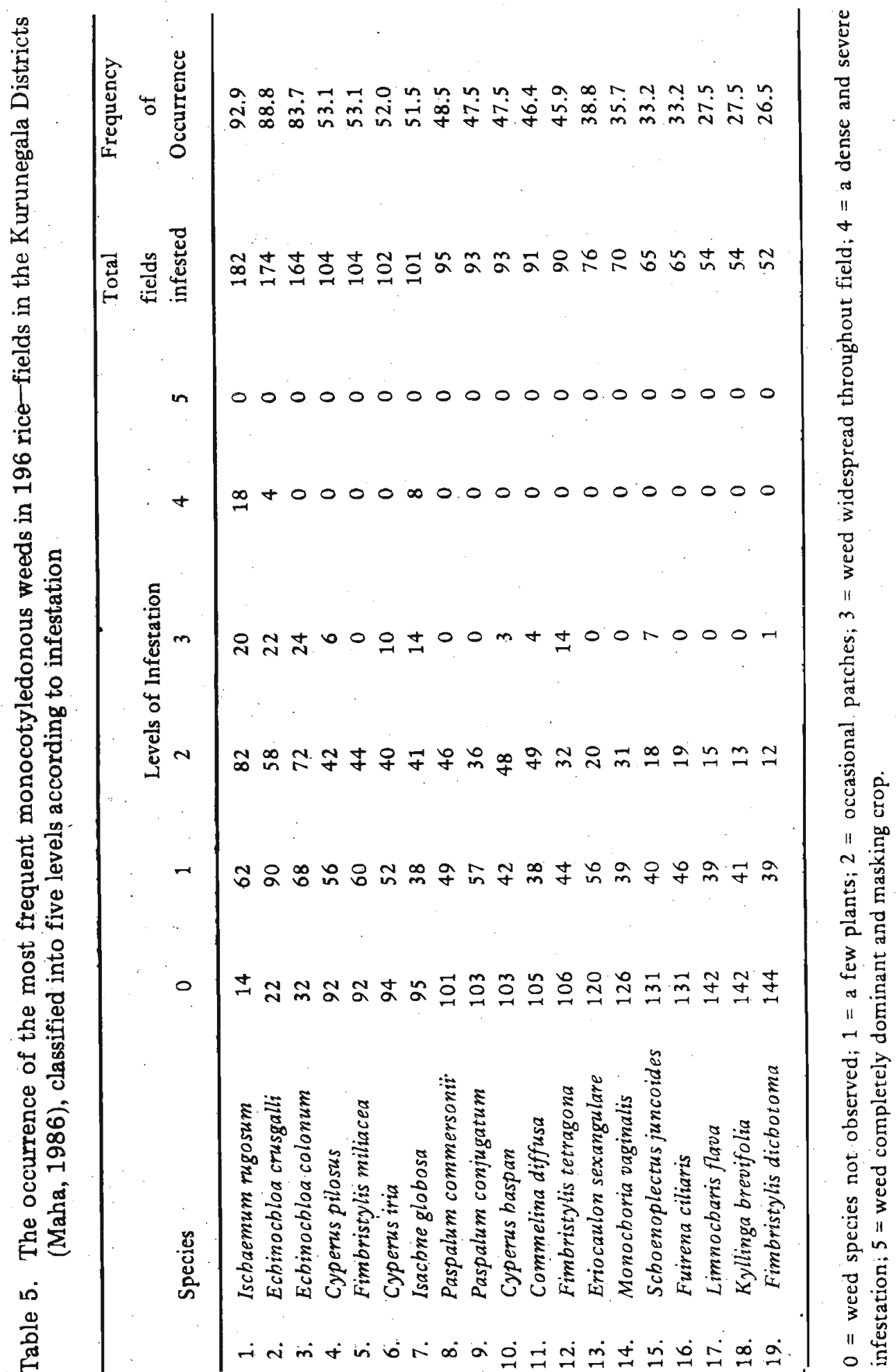




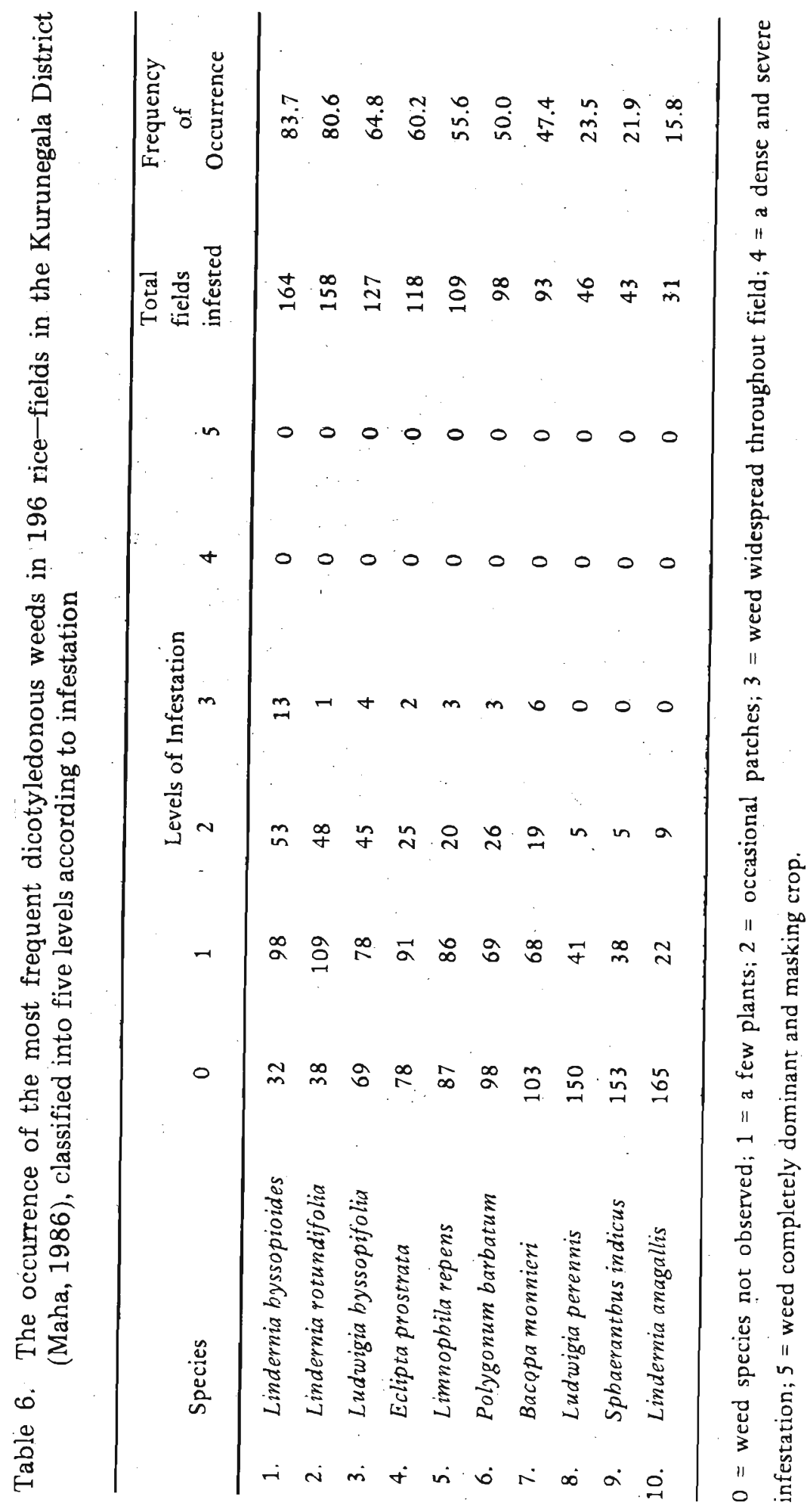


Ludwigia hyssopifolia emerged as the 3rd most frequent dicotyledonous weed with a frequency of occurrence of $65 \%$. However, its infestations too were not found to be very heavy. Ludwigia perennis, which was found only in the drier part of the Ratnapura District, occurred in $23 \%$ of fields sampled in Kurunegala, mainly towards the East and South-East border of the District, under similar semi-dry to wet conditions. In the present ricefield weed surveys this species has not been found in the wet to very-wet rice-fields of the Gampaha, Colombo and Galle Districts, while it was recorded in only one rice-field sampled in the Kalutara District (unpublished data). The third species, L. decurrens, was not found in the Kurunegala District in any of the fields studied or in nearby habitats, suggesting that this species has not yet spread to the District.

Among the dicotyledonous weeds of the rice-fields in the District, a Polygonum species, namely Polygonum barbatum, acquired importance in $50 \%$ of fields sampled. This species was found to infest bund habitats of many fields and invading the field-habitat also quite frequently.

\section{Weed-flora of Rice-field Bunds}

Table 2, which records the habitat occupied by the weeds, indicates the species which were prevalent on the bunds. The more important species of this habitat for the two Districts are given in Tables 7 and 8 . As in the Districts studied previously, weeds of the bund habitat consisted mainly of a large number of semi-aquatic and terrestrial species. In both Districts the commonest weeds of the bunds were $I$. globosa and Eragrostis unioloides. Eragrostis unioloides was noted to be occupying only the bund habitat, while nearly all the other species were recorded in the field habitat as well. Fimbristylis miliacea, $P$. commersonii, Panicum repens and $C$. diffusa were also very common on the bunds of rice-fields in both districts.

Lindernia hyssopioides, L. rotundifolia, E. prostrata, Leucas zeylanicus, Ludwigia hyssopifolia, and Borreria alata were the commonest dicotyledonus weeds present on the bunds of both Districts.

However, in the drier Kurunegala District, very often a large number of cosmopoliton, terrestrial weed species were found to have invaded the rice agroecosystem, occupying the bund habitat. Among these were: Gomphrena celosioides, Ageratum conyzoides, Tridax procumbens, Vernonia cinerea, Heliotropium indicum, Cleome viscosa, Euphorbia hirta, Mimosa pudica, Hyptis suaveolens, Urena lobata, Sida rhombifolia, Phyla nodiflora and Stachytarpheta indica. In the Ratnapura District as well, such weeds were common in the drier regions of the south-east. Since these are generally opportunistic species it is probable that their presence in the rice agroecosystem is only incidental and does not cause much concern to rice culture. 


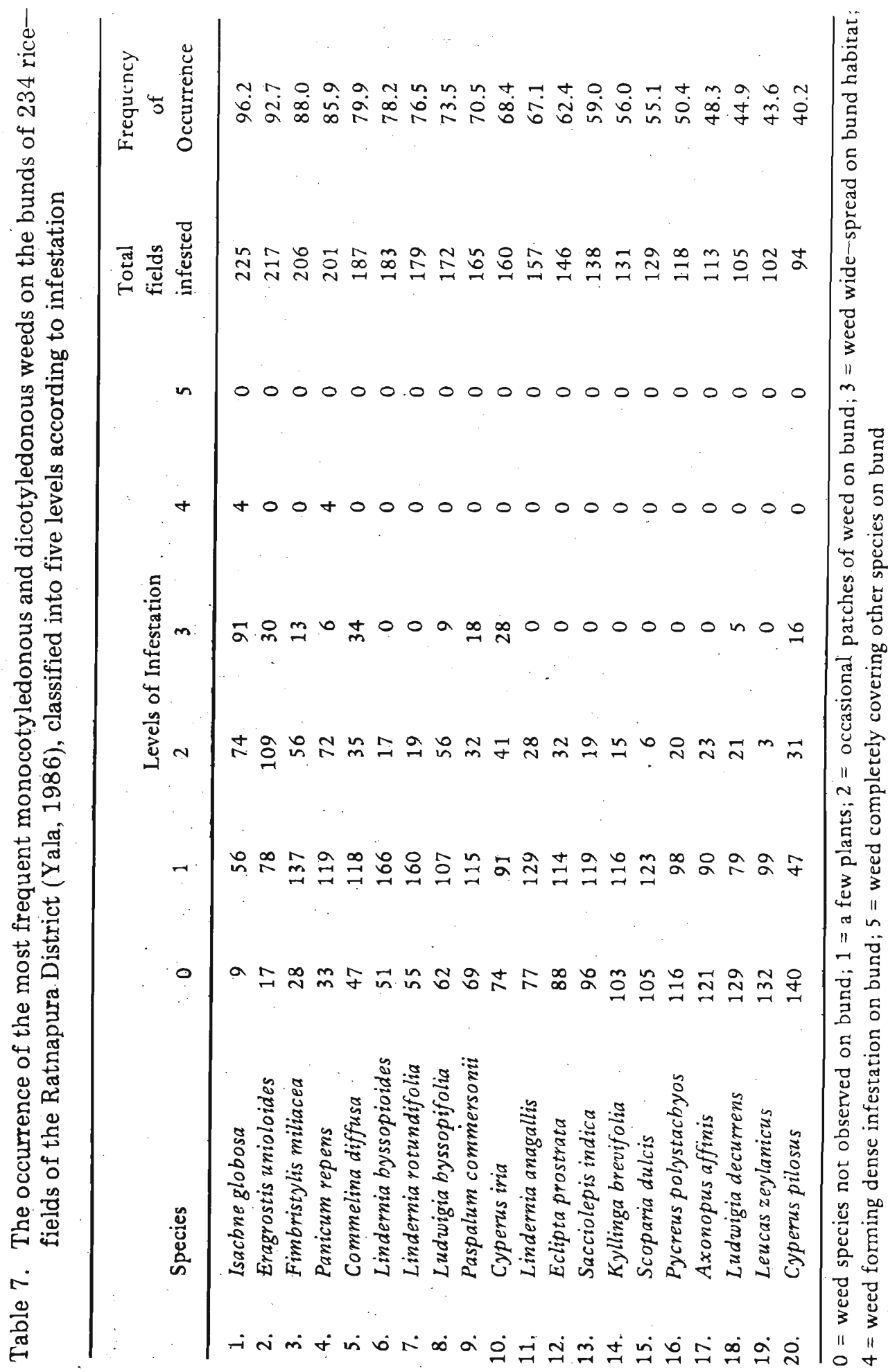




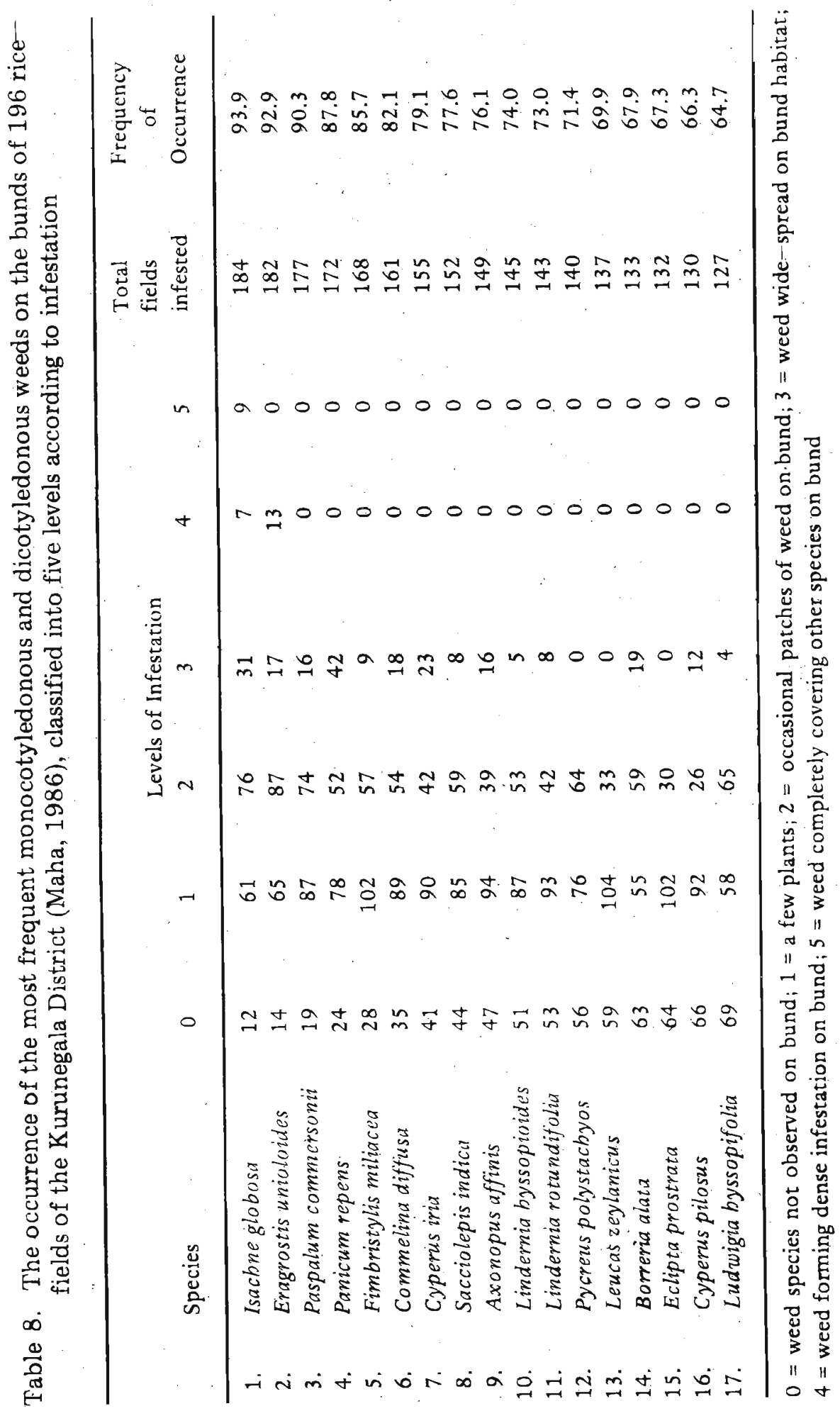




\section{General Observations}

As explained previously, the present survey was carried out in fields when the rice was at heading to flowering stages, and after the farmers had manually weeded the fields, or had applied herbicides for weed control. Hence, the majority of the species recorded in the survey were probably those weeds which had survived control efforts of the farmers. It was also possible that some of the weeds recorded had grown out of seeds which germinated after the farmers had carried out their control measures. It is logical to think that the species which survived control measures were the ones that are most likely to pose the greatest problems as weeds. However, it is noted that succesful weed control by either method would have led to an underestimation of the actual abundance of weeds in the present survey.

Major differences in the weed-flora were not observed between the two Districts. Nearly all the major weed species were common to both Districts. It was obvious from the survey that rice-fields contain a wide variety of weeds in both Districts. Information on the extent of yield reduction caused by them, or other adverse effects of such a diverse flora, is not presently available.

Three monocotyledonous species, namely E. crus galli, E. colonum and $I$. rugosum, represented the most troublesome weeds. Not only were these species abundant in terms of frequency of occurrence, but also in terms of the levels of their infestations, which were generally heavy. Ischaemum rugosum is undoubtedly a very important weed in both Districts, and despite the fact that a fair proportion of fields in Kurunegala were found suffering due to inadequate moisture in mid-season, this weed was well established. Pablico and Moody ${ }^{6}$ in a recent study of rice-weeds in the Central and Southern Philippines, stated that I. rugosum was a much less important component of the weed-flora in the dry-season than in the wet-season. However, in Sri Lanka the domination achieved by I. rugosum points to the fact that the weed is able to adjust itself to a wide range of moisture situations.

Ludwigia hyssopifolia was the most important dicotyledonous weed found in the two Districts. It is probable that this weed too is able to withstand a wide range of moisture conditions.and become well established.

The farmer interviews clearly indicated that the farmers lacked adequate knowledge about the weeds, their adverse effects and effective management. The majority of farmers only carried out several hand-weeding operations, while others used the herbicides MCPA and 3,4-DPA (Propanil). for early-season weed control. A small percentage of farmers was found to have used Paraquat, the defoliant, desiccant herbicide for killing mainly the grass-weed cover dominated by I. globosa, just prior to land preparation. Many farmers expressed the view that the agricultural extension service was not effective enough with advice, and that this was a major problem faced by them. 


\section{Acknowledgements}

The author is grateful to the Natural Resources, Energy and Science Authority of Sri Lanka (NARESA) for the research grant $\mathrm{RG} / 86 / \mathrm{B} / 4$ which enabled this survey to be carried out, and to the Department of Botany, University of Colombo, for its support and facilities for the research.

\section{References}

1. CHANDRASENA, J. P. N. R. (1987a) int. Rice Res. Nezsletter, 12(8); 32 .

2. CHANDRASENA. J. P. N. R. (1987b) J. Natn. Sci Coun. Sri Lanka, 15(2), 249-265.

3. CHANDRASENA, J. P. N. R. (1988a) Trop. Pest Managcment, 34(3): 291-297.

4. CHANDRASENA, J. P. N. R. (19880) J. Natn. Sci. Coun. Siri Lanka, 16(1); 97-103.

5. MOODY, K. \& DROST. D. C. (1983) In Weed Control in Rice. pp. 73-88, International Rice Res. Institute, Los Banos, Laguna, Philippines.

6. PABlico, P. P. \& MOODY, K. (1986) Pbilip.J. Weid Sii. $13: 3949$.

7. WEERAKOON, W. L. \& GUNAWARDENA. S. D. 1. E. (1983) Trop. Agri, $139: 1-14$ 